\title{
Carbon and nitrogen allocation in trees
}

\author{
R.E. Dickson
}

USDA-Forest Service, NCFES, Rhinelander, WI, U.S.A.

\section{Introduction}

Growth of trees and all plants depends upon maintaining a positive carbon balance despite continually changing environmental stresses. Under natural conditions, growth is commonly limited by several environmental stresses operating at the same time. Thus, growth is the summation of a plant's response to multiple environmental stresses (Chapin et al., 1987; Osmond et al., 1987). Light, carbon, water and nitrogen are fundamental factors most likely to limit growth. On a world-wide basis, water availability is probably the major factor limiting plant growth (Schulze et al., 1987). However, in many temperate and tropical forests, nitrogen availability is the most critical limiting factor (Agren, 1985a). Thus, information provided by studies of carbon and nitrogen metabolism and their interactions is necessary to understand plant growth.

There has been an enormous amount of research on carbon and nitrogen interactions and plant growth, primarily with agricultural plants and primarily directed towards harvestable plant parts. However, compared to agronomic crops, we have only limited knowledge of carbon and nitrogen interactions and growth for any species in natural ecosystems. Although there have been many studies on component biomass, nutrient content, and net primary production, the results are difficult to interpret and generally do not provide information on changes over time in varying environments. The primary reason for interpretation problems is the lack of 'standard' carbon allocation data sets developed for trees grown under 'optimum' conditions to compare with carbon allocation patterns found in stress situations. A major objective of tree research should be to develop such 'standard' data sets on a few key or indicator species. Then carbon and nitrogen allocation patterns found in trees under stress can be interpreted, and changes in allocation can be predicted for other species and other stress situations.

In this paper, I plan to review the current literature on carbon and nitrogen allocation (the movement of carbon within the plant) in trees. Because of space limitations and other recent reviews on the regulation of carbon partitioning (carbon 
flow among different chemical fractions over time) at the cellular level (Champigny, 1985; Huber, 1986; Geiger, 1987), partitioning will not be addressed. Even after many years of research, we still know little about the processes involved and the factors that regulate carbon and nitrogen allocation in trees. Quantitative information on basic allocation patterns and how these patterns change during the season is available for only a few annual plants of agronomic importance (Pate, 1983). No such detailed quantitative information on carbon and nitrogen allocation is available for any tree species. However, there is considerable descriptive information for carbon allocation in Populus (Isebrands and Nelson, 1983; Dickson, 1986; Bonicel et al., 1987), and for carbon and nitrogen allocation in fruit trees (Titus and Kang, 1982; Tromp, 1983; Kato, 1986).

All plants allocate carbon to maximize competitive fitness, reproduction, and growth within their various plant communities. Plants in different environments have different 'strategies' for allocation depending upon their life-forms (Schulze, 1982). Annual crop plants with basically four seasonal growth phases - early vegetative, flowering, seed fill, and senescence have been the subject of most studies on carbon and nitrogen allocation. These lifeforms are relatively simple and there is much economic incentive to understand their basic biological mechanisms in order to manipulate growth and yield. In comparison, trees, which may live from 50 to more than 5000 years, are much more difficult experimental subjects. During their lives, trees go through several different growth stages: seedlings, saplings, polestage, mature flowering and fruiting, and senescence. Each stage is characterized by increasingly complex crown morphology and allocation patterns. In addition, seasonal growth phases also alter allocation patterns (Dickson and Nelson, 1982;
Smith and Paul, 1988). Additional complexities and differences arise between deciduous and evergreen trees. Deciduous and evergreen trees use different strategies to maximize carbon gain and utilization of both internal and external resources (Schulze, 1982). Deciduous trees rapidly renew all of their leaves in the spring at a relatively low carbon cost per unit leaf area but at a high cost of stored carbohydrate. Deciduous leaves are also very productive per unit leaf area, and much of the carbon fixed after leaf development is available for growth of stems and roots or for storage. In contrast, carbon costs of evergreen leaves are relatively high (Pearcy et al., 1987). However, only a small portion of total leaf mass is renewed each year. Carbon fixation continues in older leaves and overall carbon gain may be similar to rapidly growing deciduous trees (Matyssek, 1986). Although patterns of carbon fixation, partitioning to different chemical fractions, allocation within the plant and cycling within the plant may differ between and among deciduous and evergreen trees in many details, the major seasonal patterns of carbon and nitrogen allocation are very similar.

\section{Carbon allocation in trees}

Crop scientists have long recognized that carbon allocation is a major determinant of growth and yield (Gifford et al., 1984) and have organized research programs accordingly. Understanding 'standard' carbon allocation patterns in trees would provide the background information necessary for interpreting how these patterns change with stress and would provide the knowledge necessary to develop physiologically based management strategies and genetic improvement programs. 


\section{Leaf development and carbon transport}

Structural development and physiological processes change continuously from leaf initiation to full maturity. These changes are not uniform throughout the lamina but progress from tip to base in most plants. The onset of translocation from a particular lamina region is the best indicator of tissue maturity. Translocation begins after the sieve element-companion cell complex matures and a translocatable product is produced in the tissue (Dickson and Shive, 1982). The simple leaf of cottonwood (Populus deltoides Bartr. Marsh.) provides a good example of this developmental pattern. Both anatomical and ${ }^{14} \mathrm{C}$ transport studies show that leaf maturity begins at the lamina tip and progresses basipetally. In contrast to cottonwood, the compound leaves of green ash (Fraxinus pennsylvanica Marsh.) and honeylocust (Gleditsia triacanthos L.) mature first at the base. Basal leaflets may translocate both to developing distal leaflets and out of the leaf (Larson and Dickson, 1986). However, not all compound leaves develop in this manner. In tomato (Lycopersicon esculentum L.), terminal leaflets mature first and leaf development is from tip to base (Ho and Shaw, 1977). Northern red oak (Quercus rubra L.) has a simple leaf with yet another developmental pattern. Red oak leaf and stem growth is episodic with one or several flushes of growth each growing season. Within a flush, all the leaves of that flush expand and mature at about the same time, although there is an acropetal developmental gradient within the flush. Northern red oak leaves become autotrophic (they no longer import photosynthate from older leaves) at about $50 \%$ of full expansion. Transport of photosynthate out of the leaf begins at the lamina base at about $50-60 \%$ of full leaf expansion and from the whole leaf at

Table I. Distribution of $\left[{ }^{14} \mathrm{C}\right]$ photosynthate within leaves of actively growing cottonwood plants.

\begin{tabular}{|c|c|c|c|c|}
\hline & \multicolumn{4}{|c|}{$\angle P I$ of source leaf } \\
\hline & \multicolumn{4}{|c|}{$\left(\%\right.$ total translocated $\left.{ }^{14} \mathrm{C}\right)$} \\
\hline $\begin{array}{l}\text { Apex } \\
\text { Leavesa }\end{array}$ & 10.7 & 9.2 & 11.4 & 8.5 \\
\hline LPI 0 & $\underline{23.5}$ & 1.5 & 3.2 & 10.2 \\
\hline 1 & 0.7 & $\underline{23.7}$ & 4.1 & 9.6 \\
\hline 2 & $\underline{27.5}$ & $\overline{0.5}$ & 20.8 & 3.2 \\
\hline 3 & 8.2 & 18.1 & 0.6 & 5.7 \\
\hline 4 & 0.4 & 2.9 & 11.6 & $\overline{0.4}$ \\
\hline 5 & - & 0.6 & $\overline{0.6}$ & 1.0 \\
\hline 6 & 0.3 & - & 0.4 & 1.0 \\
\hline 7 & 0.2 & 0.3 & - & 0.2 \\
\hline 8 & 0.1 & 0.2 & 0.1 & - \\
\hline $9-11$ & 0.0 & 0.1 & 0.3 & 0.4 \\
\hline Stem above source leaf & 22.1 & 30.8 & 29.7 & 16.7 \\
\hline Stem below source leaf & 3.3 & 4.7 & 6.5 & 13.8 \\
\hline Roots & 2.8 & 7.1 & 10.3 & 29.2 \\
\hline
\end{tabular}

Source leaves were treated with ${ }^{14} \mathrm{CO}_{2}$ and allowed to transport for $24 \mathrm{~h}$. Leaves with underlined values have direct vascular connections to the source leaf. (Adapted from Dickson, 1986.)

a In the leaf plastochron index system, leaves are numbered sequentially down the stem from the index leaf, LPI 0 (see Fig. 1). The apex sample consists of leaves and stem above LPI 0. 
about $70-80 \%$ of full leaf expansion (Dickson, unpublished results).

Carbon transport patterns in deciduous trees

Labeling studies with ${ }^{14} \mathrm{C}$ have shown that transport from source leaves to sink leaves is controlled by both the vascular connections between source and sink and relative sink demand (Vogelmann et al., 1982). For example, a source leaf on a 16-leaf cottonwood plant has vascular connections to sink leaves inserted 3 and 5 positions above the source leaf (Table I). Thus, a high percentage of photosynthate is transported to those sink leaves. In contrast, leaves inserted 1 and 4 positions above the source have no direct vascular connections to the source leaf and receive little ${ }^{14} \mathrm{C}$. The influence of sink strength is also illustrated in Table I by the percent ${ }^{14} \mathrm{C}$ incorporated into the third leaf above the source leaf (e.g., leaves at leaf plastochron index (LPI) 4 and 5 above source leaves LPI 7 and 8). As a sink leaf expands, more $\mathrm{CO}_{2}$ is fixed in situ, and the demand (sink strength) for imported photosynthate decreases. By LPI 5 (source leaf 8 ), the entire lamina is approaching maturity and imports little ${ }^{14} \mathrm{C}$. Photosynthate exported by LPI 8 is then available for younger leaves nearer the apex and for transport to lower stem and roots. Mature leaves below the source leaf normally do not import photosynthate directly from distal source leaves but may import carbon (e.g., amino acids) that has cycled through the root system (Dickson, 1979).

Leaf development and transport patterns within small trees are also fairly consistent. In 16-leaf cottonwood plants, the transition from upward to downward transport takes place quickly because of the small number of leaves on the plant (Fig. 1). If a 16-leaf plant were divided into
3 leaf zones, approximately the top 5 leaves (LPI 0-5) would be expanding and importing photosynthate, the middle 5 leaves (LPI 6-10) would be transporting both acropetally and basipetally in varying degrees, and the bottom 5 leaves (LPI 11-15) would be transporting primarily to lower stem and roots (Fig. 1). In larger plants (e.g., with 45 leaves), essentially the same divisions hold except there are more leaves (about 15) in each leaf zone. These same developmental and transport patterns would be found in all trees with indeterminate growth.

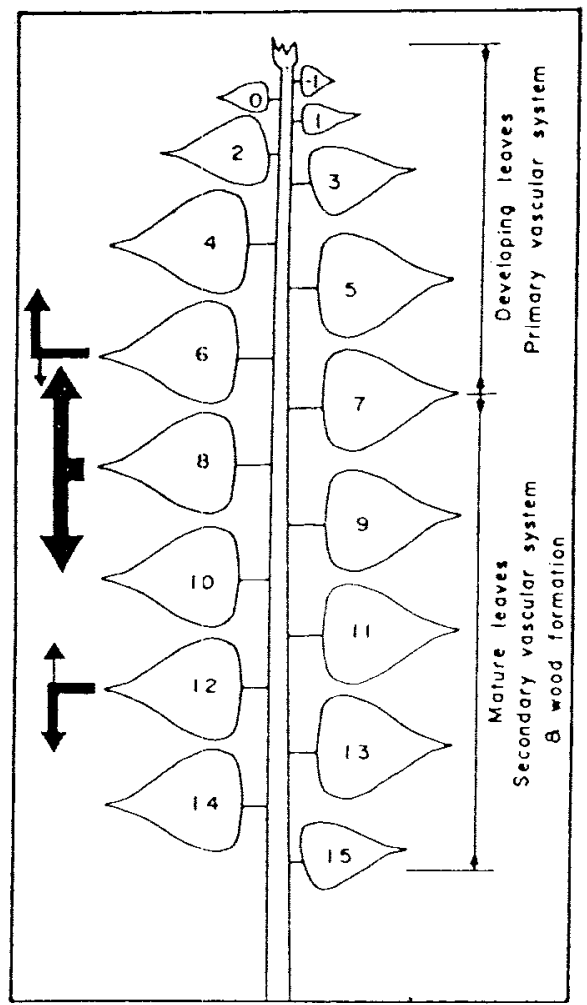

Fig. 1. Diagram of a 16-leaf cottonwood plant showing the leaf plastochron index numbering system, developing and mature leaf zones, and the direction and relative amounts of photosynthate transported from different leaves. (From Dickson, 1986.) 
Developing lateral branches are also strong sinks for carbon and nitrogen. Assimilate for early development of proleptic branches (branches that develop from dormant buds on older shoots) comes from stem storage in deciduous trees and from both storage and current photosynthate in evergreen trees. Photosynthate for early development of sylieptic branches (branches that develop from current year buds) is supplied primarily by the axillant leaf (Fisher et al., 1983). Branch sink strength decreases as more foliage leaves are produced. In cottonwood, sylleptic branches become photosynthetically independent of the main plant after 10-15 mature leaves have developed (Dickson, 1986). Photosynthate produced by individual leaves on a branch is distributed within that branch in the same pattern as that described above for the main shoot of a seedling or current terminal of a larger tree. Photosynthate not required for branch growth and maintenance is trans- ported to the main stem and moves primarily downward to lower stem and roots. However, photosynthate from uppermost branches may be translocated acropetally in the main stem and used in development of the current terminal (Rangnekar et al., 1969; Dickson, 1986).

Within-plant carbon allocation patterns are strongly influenced by sink strength of developing leaves. The transport of carbon within northern red oak seedlings is a good example of this phenomenon. During a flushing episode (e.g., 2 leaf linear, Fig. 2) more than $90 \%$ of the ${ }^{14} \mathrm{C}$ translocated from first flush leaves was directed upward to developing second flush leaves and stem, while about $5 \%$ was found in lower stem and roots. During the lag phase, when second flush leaves were fully expanded, only about $5 \%$ of the ${ }^{14} \mathrm{C}$ exported from first flush leaves was translocated upward, while $95 \%$ was translocated downward to lower stem and roots.

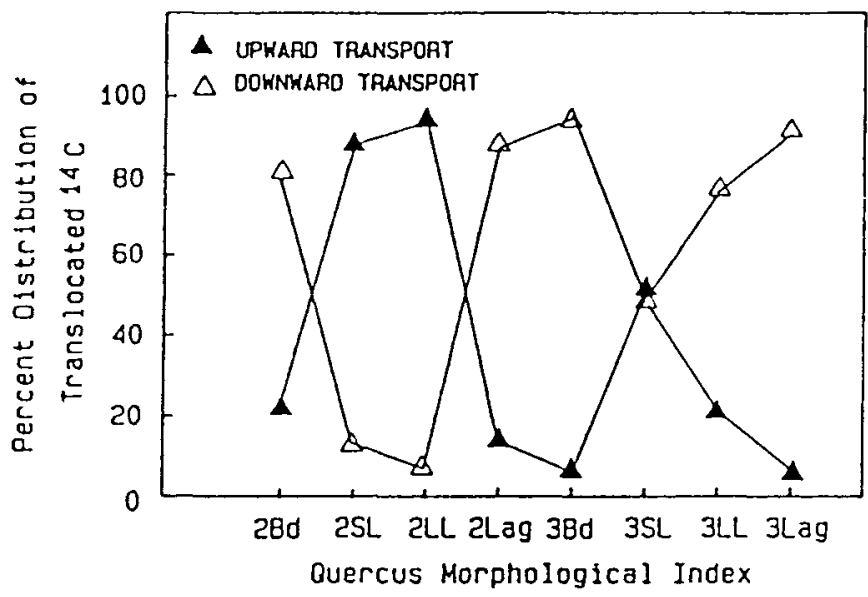

Fig. 2. Distribution of translocated ${ }^{14} \mathrm{C}$ within Quercus rubra seedlings during two flushes of growth. Percentages are based on total ${ }^{14} \mathrm{C}$ recovered in different plant parts $48 \mathrm{~h}$ after ${ }^{14} \mathrm{CO}_{2}$ treatment of a first flush source leaf. Upward transport = sum of all ${ }^{14} \mathrm{C}$ found in leaves and stem above the first flush. Downward transpit = sum of all ${ }^{14} \mathrm{C}$ found in first flush stem and roots. Developmental stages based on the Quercus morphological index (Hanson et $a l$., 1986), i.e., $28 \mathrm{~d}$, developing bud of the second flush $2 \mathrm{~cm}$ long; $2 \mathrm{LL}$, leaf linear growth stage - middle leaves of the second flush rapidly expanding; 2 Lag, second flush leaves are fully expanded. 
First flush leaves responded again during the third flush of growth with upward translocation of ${ }^{14} \mathrm{C}$, even though the mature leaves of the second flush were also translocating upward. Such shifts in the direction of translocated photosynthate is probably a major contributing factor to the out-of-phase periodicity of shoot and root growth commonly observed in trees (Hoffman and Lyr, 1973; Drew and Ledig, 1980; Sleigh et al., 1984).

Carbon transport patterns in conifers and other evergreen trees

Seasonal allocation patterns of newly fixed carbon in conifers is similar to those found in deciduous trees, but with important differences. Because leaves are already present, conifers may fix carbon during warm early spring periods. Some of the carbon fixed before budbreak is stored in leaves, and some is translocated to lower stem and roots (Table II). Numerous ${ }^{14} \mathrm{C}$ allocation studies have shown that during the spring flush of growth both currently fixed and stored carbohydrates are translocated to new growth (Gordon and Larson, 1968; Schier, 1970; Webb, 1977; Smith and Paul, 1988). After new foliage begins to transport photosynthate, carbon is again allocated to lower stem and roots. This alternating pattern of upward transport to strong leaf sinks and downward transport after new leaf maturation in single flush conifers, such as red pine (Pinus resinosa), is similar to that found in single flush deciduous trees (except the carbon for new leaf development in deciduous trees comes initially from stem and root storage pools). In conifers with multiple flushes during the growing season, acropetal and basipetal transport would also be cyclic - first to strong developing

Table II. Distribution of $\left[{ }^{14} \mathrm{C}\right]$ photosynthate within young red pine (Pinus resinosa) seedlings.

\begin{tabular}{|c|c|c|}
\hline & \multicolumn{2}{|c|}{ Distribution of ${ }^{14} \mathrm{C}$} \\
\hline & $\%$ of total ${ }^{14} \mathrm{C}$ & $\%$ of exported ${ }^{14} \mathrm{C}$ \\
\hline \multicolumn{3}{|c|}{ Before bud-break } \\
\hline old needles & 43.2 & - \\
\hline stem & 27.1 & 47.7 \\
\hline roots & 29.7 & 52.3 \\
\hline \multicolumn{3}{|c|}{$\begin{array}{l}\text { During stem and } \\
\text { leaf elongation }\end{array}$} \\
\hline new needles & 48.5 & 59.1 \\
\hline new stem & 13.9 & 16.9 \\
\hline old needles & 17.9 & - \\
\hline stem & 6.9 & 8.4 \\
\hline roots & 12.8 & 15.6 \\
\hline \multicolumn{3}{|c|}{ After new needle maturity } \\
\hline new needles & 2.5 & 3.9 \\
\hline new stem & 0.4 & 0.6 \\
\hline old needles & 35.3 & - \\
\hline stem & 14.5 & 22.4 \\
\hline roots & 47.3 & 73.1 \\
\hline
\end{tabular}

One-year-old needles were treated with $0.8 \mathrm{MBq}{ }^{14} \mathrm{CO}_{2}$ at three ontogenetic stages - before bud-break, during stem and leaf elongation of the new flush, and after new needles were mature. All needles of the flush were treated and allowed to translocate for $72 \mathrm{~h}$. (Adapted from Gordon and Larson, 1968.) 
leaf sinks, then to lower stem and roots after full leaf expansion - just as in multiple flushing red oak (Fig. 2).

\section{Carbon allocation to storage}

Carbohydrate storage exhibits both diurnal and seasonal patterns. Diurnal patterns of carbon allocation were recently examined in detail (Dickson, 1987). In addition, the seasonal variation in concentration and location of various storage compounds has been examined in many tree species (Kramer and Kozlowski, 1979; Glerum, 1980; McLaughlin et al., 1980; Nelson and Dickson, 1981; Bonicel et al., 1987). Therefore in this review, I will only examine the interactions of tree growth and carbohydrate storage.

In perennial plants, excess photosynthate is stored as carbohydrates, lipids and other chemical compounds. Storage of reserves is particularly important for plants growing in areas with large seasonal climatic changes. Reserves are used for respiration and plant maintenance during the dormant season and for new growth in spring. Stored products are also used for episodic growth flushes during the growing season (Sleigh et al., 1984). Late seasona) defoliation or repeated defoliation of deciduous trees may deplete reserves and lead to branch die-back or death of the whole tree (Heichel and Turner, 1984). More importantly for tree growth and survival, defoliation may initiate a cycle in which many stress factors are involved. For example, low carbohydrate reserves in stems and roots increase susceptibility to cold winter temperatures, decrease foliage regrowth, decrease root growth, increase water stress and susceptibility to summer drought and increase susceptibility to root rots and other pathogens (Wargo and Montgomery, 1983; Gregory et al., 1986). Such multiple stresses may cause top die- back, general progressive decline and eventual death.

Allocation of carbon to storage is a relatively low priority function. With bud-set and maturation of leaves in late summer and fall, leaf sink strength decreases and assimilate is translocated to lower stem and roots. This assimilate is preferentially used for xylem development or root growth and then for storage. The timing and degree of change in direction of transport strongly depend upon the phenology of the particular clone or tree species (Isebrands and Nelson, 1983; Nelson and Isebrands, 1983; Michael et al., 1988). In addition, xylem growth and/or storage takes place at different times in different parts of a tree depending upon growth of the particular organ. Cambial activity and xylem growth generally progress as a wave from developing buds and branches, to stem, to roots (Denne and Atkinson, 1987). Thus, diameter growth of larger roots takes place much later in the growing season than stems. Starch may be stored in root tissue early in the summer before diameter growth starts (Wargo, 1979). This starch is not hydrolyzed and used for diameter growth, but remains in the ray and xylem parenchyma. This phenomenon indicates that current photosynthate is used for diameter growth and not stored assimilate. New fine root growth may also depend upon current photosynthate (van den Driessche, 1987; Philipson, 1988). Stored assimilates are used for new leaf and shoot growth in the spring and for regrowth of leaves after defoliation (Gregory and Wargo, 1986; Gregory et al., 1986). However, the degree to which current photosynthate or stored assimilate can be used for stem or root growth requires much more research with ${ }^{14} \mathrm{C}$ tracers to determine the distribution of current photosynthate between active growth and storage pools in different tissues (Glerum, 1980). 


\section{Nitrogen allocation in trees}

The major environmental factor limiting growth in many temperate forests is nitrogen availability. Many experiments conducted under controlled conditions have shown that plant growth is directly related to the internal nitrogen concentration up to some optimum concentration (Agren, 1985b; Ingestad and Lund, 1986; Ingestad and Agren, 1988). Thus, if nitrogen supply decreases, internal nitrogen concentration decreases and growth rate decreases. In addition, as the amount of functional biomass increases, the amount of nitrogen required per unit time increases and the amount of nitrogen supplied must also increase or growth rate will decrease (Ericsson, 1981; Ingestad and Lund, 1986; Ingestad and Agren, 1988).

\section{Inorganic nitrogen uptake and utilization}

Forest ecosystems contain large amounts of nitrogen, of which more than $90 \%$ is organically bound in plant and animal biomass, forest floor litter and soil. In contrast, plant growth depends upon the uptake of inorganic nitrogen, usually less than $1 \%$ of the total nitrogen present on site (Carlyle, 1986). Competition for this available nitrogen is intense, and higher plants have developed many strategies for the acquisition and internal maintenance of adequate levels.

Ammonium $\left(\mathrm{NH}_{4}^{+}\right)$and nitrate $\left(\mathrm{NO}_{3}^{-}\right)$are the major inorganic nitrogen ions in the soil and litter. The concentration of these ions in the root zone is controlled by the rate of mineralization and nitrification. Roots of higher plants are usually concentrated in that portion of the soil profile in which maximum net mineralization is occurring (Eissenstat and Caldwell, 1988). Nitrogen mineralization is the biologically mediated release of organically bound nitrogen and its conversion into ammonium and nitrate. Movement in the opposite direction converts inorganic nitrogen into organic forms and results in immobilization. Net mineralization will occur only when the nitrogen released by decomposition exceeds that required by the microflora (Carlyle, 1986). This occurs when the substrate $\mathrm{C}: \mathrm{N}$ ratio decreases to that of the microbial biomass; thus the $\mathrm{C}: \mathrm{N}$ ratio at which mineralization begins can be associated with site and other factors (Berg and Ekbohm, 1983). In high C:N litter, essentially all nitrogen is immobilized by microorganisms and is not available to higher plants. However, mycorrhizal associations may increase the ability of higher plants to compete for nitrogen.

Improved growth of mycorrhizal plants probably results from a greater ion absorbing surface that increases nitrogen flux from a limited supply to the plant. In addition, the direct mineralization and cycling of nitrogen by the fungus are important (Vogt et al., 1982). However, in controlled experimental systems when nitrogen addition rates were held constant, mycorrhizae did not increase nitrogen uptake even at low levels of addition and decreased relative growth rate of pine seedlings, indicating a carbon drain (Ingestad et al., 1986).

The ammonium ion $\left(\mathrm{NH}_{4}^{+}\right)$is the first ion released in mineralization, while nitrate $\left(\mathrm{NO}_{3}^{-}\right)$production (nitrification) is inhibited in many forest ecosystems (Keeney, 1980; Vitousek and Matson, 1985). Although, under certain conditions, considerable nitrification can take place (Vitousek et al., 1982; Nadelhoffer et al., 1983; Smirnoff and Stewart, 1985). Because of the limited production of $\mathrm{NO}_{3}$ and the intense competition for inorganic nitrogen, $\mathrm{NH}_{4}$ is the most common nitrogen form available to higher plants in some forest ecosystems. In undisturbed forests, the $\mathrm{NH}_{4} \mathrm{NO}_{3}$ ratio is approximately 10:1 (Carlyle, 1986). 
However, tree species in other forest ecosystems and on different sites may be exposed to wide variations in the $\mathrm{NH}_{4} / \mathrm{NO}_{3}$ ratio (Nadelhoffer et al., 1985).

Ammonium and nitrate ions differ greatly. Ammonium is the most reduced form of nitrogen, while nitrate is the most oxidized; therefore, absorption of these ions is affected differently by $\mathrm{pH}$, temperature, ion composition of the soil solution, carbohydrate supply in the roots and many other factors (Bernardo et al., 1984). Specific, active uptake systems are present in roots for both ions (Runge, 1983). However, passive diffusional uptake may also occur (Lee and Stewart, 1978). Once absorbed by the root, $\mathrm{NH}_{4}$ is rapidly combined with glutamate to form glutamine, a major transport and metabolically active amide (Lee and Stewart, 1978; Pate, 1983; Runge, 1983; Kato, 1986). Little $\mathrm{NH}_{4}$ is translocated to shoots in the xylem. In contrast, $\mathrm{NO}_{3}$ may be translocated in xylem to stem or leaves before metabolism, stored within cells or reduced immediately in the root by nitrate reductase. With nitrate reductase, $\mathrm{NO}_{3}$ is reduced through a series of steps to $\mathrm{NH}_{4}$, then to some transport or storage organic nitrogen compound (usually glutamine or asparagine). The functioning, location, carbon costs and energetics of the nitrate reductase system have been the focus of many studies in crop plants and weeds (Smirnoff and Stewart, 1985; Andrews, 1986; Keltjens et al., 1986; Rufty and Volk, 1986; Mackown, 1987), in fruit trees (Titus and Kang, 1982; Kato, 1986), and in forest trees (Blacquiere and Troelstra, 1986; Wingsle et al., 1987; Margolis et al., 1988). The absorption and utilization of ammonium vs nitrate, the extent to which nitrate is reduced or stored in the root or transported to leaves, the extent to which it is reduced or stored in leaves, and the kinds of transport and storage compounds involved for a particular species have important ecological and energetic implications. Basic information in these areas is severely lacking for forest trees.

Plants have evolved a wide range of contrasting life-forms and nutritional strategies because of the extreme environmental variability in $\mathrm{NH}_{4}$ and $\mathrm{NO}_{3}$ availability, the importance of maintaining an internal supply of $\mathrm{N}$ for growth and the importance of minimizing carbon costs of assimilation (Schulze, 1982; Chapin, 1983; Chapin and Tryon, 1983). Little is known about differences in nutritional strategies among forest species on a particular site or within genera on different sites. For example, different oak species are found on sites that differ widely in nitrogen economies (relative $\mathrm{NH}_{4}: \mathrm{NO}_{3}$ availability). How do different species, such as northern red oak (Quercus rubra L.) or pin oak (Q. palustris Muenchh.), assimilate ammonium or nitrate in response to differing environmental variables to maximize growth or competitive ability?

The ability to utilize both $\mathrm{NH}_{4}$ and $\mathrm{NO}_{3}$ differs widely among species. When supplied with $\mathrm{NH}_{4}, \mathrm{NH}_{4}: \mathrm{NO}_{3}$ or $\mathrm{NO}_{3}$, species of Alnus, Pinus, Picea and Pseudotsuga grow best in the order $\mathrm{NH}_{4}>\mathrm{NH}_{4}: \mathrm{NO}_{3}>$ $\mathrm{NO}_{3}$. Many plants (including tomato and certain weeds, like Chenopodium) grow best with $\mathrm{NO}_{3}>\mathrm{NH}_{4}: \mathrm{NO}_{3}>\mathrm{NH}_{4}$ (Runge, 1983; Kato, 1986; Salsac et al., 1987). However, there is much contradictory literature concerning growth and nitrogen source, even on the same species (Titus and Kang, 1982; Kato, 1986). Much of this controversy is related to uncontrolled experimental variables. For example, results of fertilizer experiments with $\mathrm{NH}_{4}$ or $\mathrm{NO}_{3}$ in soils must be viewed with caution because nitrification rates are usually not controlled or measured. In addition, large $\mathrm{pH}$ changes in solution culture or soils can result from differential uptake of $\mathrm{NH}_{4}$ or $\mathrm{NO}_{3}$. Even in buffered soils or solution culture, steep $\mathrm{pH}$ gradients can 
build up within and near roots. In unbuffered $\mathrm{NH}_{4}$ solution culture, $\mathrm{pH}$ can decrease from 7 to 3 within $48 \mathrm{~h}$ (Runge, 1983). Thus, without careful experimental control, growth differences attributed to different nitrogen sources may instead reflect the species response to extreme $\mathrm{pH}$ and the associated changes in cation and anion availability, rather than the plant's ability to assimilate different nitrogen sources. For example, metabolic iron deficiency is common in some plants utilizing $\mathrm{NO}_{3}$. High $\mathrm{pH}$ (above 6.5) in the root environment can inhibit iron uptake, while high internal levels of organic acids may chelate and inactivate absorbed iron (Runge, 1983). In contrast, high levels of $\mathrm{NH}_{4}$ can decrease soil $\mathrm{pH}$ and cation uptake, increase loss of cations from root tissue and lead to cation (e.g., $\mathrm{K}, \mathrm{Mg}, \mathrm{Ca}$ ) deficiencies (Boxman and Roelofs, 1988).

Plants have many strategies for balancing internal pH (Raven, 1985). The most common is the production of organic acids. In this reaction, dark-fixation of $\mathrm{CO}_{2}$ generates $\mathrm{H}^{+}$, consumes $\mathrm{OH}^{-}$and produces organic acids. These acids can be precipitated (oxalic), stored in vacuoles or transported back to the root along with $\mathrm{K}^{+}$ in the phloem (Bown, 1985; Raven, 1985; Allen and Raven, 1987). The ability of a particular plant species to reduce nitrate in either roots or shoots, to produce organic acids, to transport cations to balance internal $\mathrm{pH}$ and to adjust osmotically to water stress largely determines the ability to assimilate different nitrogen sources (Arnozis and Findenegg, 1986; Salsac et al., 1987).

\section{Organic nitrogen transport}

Inorganic nitrogen taken up by roots is rapidly converted into organic nitrogen compounds for translocation within the plant. Sugars, organic acids and amino acids are translocated from shoots to roots in the phloem, converted into organic nitrogen compounds and retranslocated back to shoots in the xylem (Dickson, 1979; Pate, 1980; 1983). The amount and kind of organic nitrogen compounds translocated in xylem differ with plant species (Barnes, 1963; Pate, 1980), plant developmental stage, season of the year (Sauter, 1981; Tromp and Ovaa, 1985; Kato, 1986), the amount or kind of inorganic nitrogen available to roots (Weissman, 1964; Peoples et al., 1986) and perhaps other environmental factors. The two amides, asparagine and glutamine, are major transport compounds in trees and many other plants and move readily in both xylem and phloem (Bollard, 1958; Pate, 1980; Dickson et al., 1985; Schubert 1986). In addition to glutamine and asparagine, many other amino acids and ureides are transported in xylem (Barnes, 1963; Titus and Kang, 1982; Kato, 1986). Although 5-15 amino acids are commonly found in xylem sap (Dickson, 1979), as many as 25 amino acids and ninhydrinpositive compounds have been found (Sauter, 1981; Kato, 1986). In spite of the large number of amino compounds found in xylem, only the amides, asparagine and glutamine; the amino acids, glutamate, aspartate, arginine and proline; and the ureides, allantoin, allantoic acid and citrulline, are common and major transport compounds (Barnes, 1963; Pate, 1980; Kato, 1986; Schubert, 1986).

The presence of a relatively large number of different amino compounds in xylem and phloem raises a number of important functional questions. The ureides and amides have low carbon/nitrogen ratios (e.g., allantoin, 1:1; citrulline, 2:1, asparagine, 2:1; glutamine, 2.5:1) and are efficient forms for storing and transporting nitrogen in respect to carbon required. Asparagine also has the characteristics (i.e., high solubility, stability and mobility in 
xylem and phloem) required for efficient nitrogen transport. In contrast, arginine, an important nitrogen storage compound frequently found in xylem sap, does not have the mobility of asparagine or glutamine. At xylem sap $\mathrm{pH}$, arginine is absorbed onto the cell walls and seems to move by sequential cation exchange like calcium (Pate, 1980).

The transport of different amino acids in xylem is influenced by xylem sap pH (van Bel et al., 1981). At xylem sap pH (usually 5.5-6.0) the general uptake pattern is basic > neutral > acidic amino acids. Therefore, alanine and arginine are rapidly absorbed from the xylem free-space, while glutamic and aspartic acids move with the xylem sap into transpiring mature leaves. Because of this $\mathrm{pH}$-regulated differential uptake in xylem, three distributional patterns were found in cottonwood (Vogelmann et al., 1985). 1) Alanine was taken up and retained in the stem with little transport to either phloem or developing leaves. 2) Threonine and glutamine were removed from the xylem free-space in the stem and were transferred from primary xylem to secondary xylem, from xylem to phloem, and were then translocated to developing leaves in both xylem and phloem. 3) Aspartic and glutamic acids were not strongly absorbed by stem tissue but moved with the xylem sap into mature leaves. These amino acids were then either metabolized in mature leaf tissue or loaded into the phloem for retransport to developing leaf or stem and root sinks.

Carbohydrate transport to roots, nitrogen uptake, production of amino acids, and transport back to shoots are closely controlled feedback cycles regulated by demand of both shoots and roots for carbohydrate and nitrogen necessary for growth. The differential production of amino acids and other transport nitrogen compounds in roots and the different distributional patterns in shoots of these nitrogen compounds provide metabolic mechanisms for regulation of the nitrogen composition of both xylem and phloem; for uptake, distribution and recycling of nitrogen within the plant; and for selective allocation of nitrogen to various sinks in the plant. In forestry research, there is a critical need for information about nitrogen transport in trees. Little is known about the mechanism of uptake, metabolism and allocation of these compounds; the carbon costs of uptake, metabolism and transport; and how these factors change with plant ontogeny and environmental stress.

\section{Organic nitrogen storage}

The temporary storage of carbon and nitrogen is necessary for normal plant growth. The major cycles of nitrogen storage and utilization are seasonal and associated with changes in tree growth, although some diurnal cycling is found (Dickson, 1987). These cycles have been studied mainly in fruit trees and have been recently reviewed (Glerum, 1980; Stassen et al., 1981; Titus and Kang, 1982; Tromp, 1983; Kato, 1986).

In annual plants, considerable nitrate and amino acids may accumulate in leaves if nitrogen uptake exceeds growth demands of the plant (Pate, 1983). In addition, nitrogen can accumulate in vegetative tissue as proteins. Ribulose 1,5-bisphosphate carboxylase, the major functional protein in leaves, may be defined as a storage protein in that it is accumulated during vegetative growth and then hydrolyzed and used in reproduction (Millard, 1988). Specific storage proteins may also accumulate in specialized mesophyll cells of certain legumes (Franceschi et al. 1983) These storage proteins are hydrolyzed during leaf senescence and the carbon-nitrogen compounds releaseo are used for seed production. 
In perennial plants, nitrogen is stored both in soluble amino compounds and in protein. There is controversy over whether soluble nitrogen compounds or proteins are more important (Tromp, 1983). In apple trees, in late November when protein accumulation in bark peaked, Kang and Titus (1980) found about $90 \%$ of the nitrogen in protein and about $10 \%$ in soluble amino compounds. The relative proportions of soluble versus insoluble nitrogen compounds vary with the season, within different parts of the tree, with fertilization, with different extraction methods and with changing environmental conditions (Kato, 1986).

The major soluble nitrogen storage compounds are arginine, proline, asparagine and glutamine. The particular nitrogen compounds accumulated are quite species specific, and different species may be grouped according to the major free amino acid present during storage (Sagisaka and Araki, 1983). Arginine, proline or a combination of these two amino acids are the major soluble nitrogen storage compounds in most trees (Titus and Kang, 1982; Kato 1986). Although arginine is a major storage amino acid, it is usually converted into asparagine or glutamine for transport from storage tissue to new developing tissue (Tromp and Ovaa, 1979). These transformations from storage to transport compounds were inferred from changes in the concentrations of the individual amino acids. However, little is known about the specific metabolic reactions involved (Sieciechowicz et al., 1988). Proline is the major soluble amino acid in dormant citrus (Kato, 1986). However, because proline is not a carbon efficient storage compound (C:N, 5:1), it must have some important metabolic function in dormant and stressed plants (Hanson and Hitz, 1982).

The presence of storage proteins in tree tissue has been recognized for a long time. However, until the recent develop- ment of better extraction techniques, few detailed studies were conducted. Studies on Salix (Sauter and Wellenkamp, 1988) have shown that storage proteins are located in vacuoles of ray cells, and gel electrophoretic studies of these Salix proteins and others from ginkgo bark (Shim and Titus, 1985) have begun to characterize these storage proteins. These proteins are rich in arginine and other basic amino acids (Kang and Titus, 1980), accumulate in the fall, disappear in the spring and are glycoproteins similar to those found in soybean (Franceschi et al., 1983). However, little is known about these storage proteins in trees. In-depth studies are clearly needed of their deposition, hydrolysis, chemical composition and response to fertilization and environmental stress.

Nitrogen storage usually begins as soon as new leaf and shoot growth slows in early summer. The initiation of storage is often indicated by an increase in arginine concentration in small branches and bark tissue. Both soluble and protein nitrogen gradually increase during the summer as growth slows, then rapidly increase as leaves begin to senesce. Leaves on small trees may contain up to $50 \%$ of the total nitrogen in the plant, and $75-80 \%$ of that nitrogen may be retranslocated back into stems before leaf abscission (Chapin and Kedrowski, 1983; Cote and Dawson, 1986; Tyrrell and Boerner, 1987). Nitrogen accumulation continues late into the fall in the main stem and roots as soluble nitrogen moves from twigs to main stem, and newly absorbed inorganic nitrogen is converted into organic nitrogen and stored in roots (Tromp, 1983; Kato, 1986).

In evergreen trees, leaves and needles as well as stem and roots are important sites for nitrogen storage. Nitrogen is stored during periods of inactive growth and then retranslocated to new developing leaves and shoots during flushing. In 
Citrus, a tropical evergreen tree with an episodic flushing growth habit, nitrogen used in the new flush comes largely from storage. By measuring the nitrogen content of different tree parts before and after the spring growth flush, Kato (1986) found that nitrogen in the new flush came from mature leaves $(20 \%)$, stem $(40 \%)$, roots $(30 \%)$ and the soil $(10 \%)$. Similarly, Nambiar and Fife (1987) found that up to $54 \%$ of the nitrogen in mature needles was translocated to the developing flush in Pinus radiata. Nitrogen fertilization increased the nitrogen content of mature needles of $P$. radiata and also increased the proportion of nitrogen in the needles that was translocated to the new flush. Thus, we need to carefully examine the usual view that retranslocation and cycling of nitrogen in plants increase with nitrogen stress, for these functions may be very different in different species and different lifeforms.

\section{References}

Agren G.I. (1985a) Limits to plant production. $J$. Theor. Biol. 113, 89-92

Agren G.l. (1985b) Theory for growth of plants derived from the nitrogen productivity concept. Physiol. Plant. 64,17-28

Allen S. \& Raven J.A. (1987) Intracellular pH regulation in Ricinus communis grown with ammonium or nitrate as $N$ source: the role of long distance transport. J. Exp. Bot. 38, 580596

Andrews M. (1986) The partitioning of nitrate assimilation between root and shoot of higher plants. Plant Cell Environ. 9, 511-519

Arnozis P.A. \& Findenegg G.R. (1986) Electrical charge balance in the xylem sap of beet and sorghum plants grown with either $\mathrm{NO}_{3}$ or $\mathrm{NH}_{4}$ nitrogen. J. Plant Physiol. 125, 441-449

Barnes R.L. (1963) Organic nitrogen compounds in tree xylem sap. For. Sci. 9, 98-102
Berg B. \& Ekbohm G. (1983) Nitrogen immobilization in decomposing needle litter at variable carbon:nitrogen ratios. Ecology 64, 63-67

Bernardo L.M., Clark R.B. \& Maranville J.W. (1984) Nitrate/ammonium ratio effects on nutrient solution $\mathrm{pH}$, dry matter yield, and nitrogen uptake of sorghum. J. Plant. Nutr. 7, 13891400

Blacquiere T. \& Troelstra S.R. (1986) Nitrate reductase activity in leaves and roots of Alnus glutinosa (L.) Gaertner. Plant Soil 95, 301-313

Boilard E.G. (1958) Nitrogenous compounds in tree xylem sap. In: The Physiology of Forest Trees. (Thimann K.V., Critchfield W.B., \& Zimmermann M.H., eds.), Ronald Press Co., NY, pp. 83-93

Bonicel A., Haddad G. \& Gagnaire J. (1987) Seasonal variations of starch and major soluble sugars in different organs of young poplars. Plant Physiol. Biochem. 25, 451-459

Bown A.W. (1985) $\mathrm{CO}_{2}$ and intracellular pH. Plant Cell Environ. 8, 459-465

Boxman A.W. \& Roelofs J.G.M. (1988) Some effects of nitrate versus ammonium nutrition on the nutrient fluxes in Pinus sylvestris seedlings. Effects of mycorrhizal infection. Can. J. Bot. 66, 1091-1097

Carlyle J.C. (1986) Nitrogen cycling in forested ecosystems. For. Abstr. 47, 308-336

Champigny M.L. (1985) Regulation of photosynthetic carbon assimilation at the cellular level: a review. Photosyn. Res. 6, 273-286

Chapin F.S. III (1983) Nitrogen and phosphorus nutrition and nutrient cycling by evergreen and deciduous understory shrubs in an Alaskan black spruce forest. Can. J. For. Res. 13, 773781

Chapin F.S. III \& Kedrowski R.A. (1983) Seasonal changes in nitrogen and phosphorus fractions and autumn retranslocation in evergreen and deciduous taiga trees. Ecology 64, 376-391

Chapin F.S. III \& Tryon P.R. (1983) Habitat and leaf habit as determinants of growth, nutrient absorption, and nutrient use by Alaskan taiga forest species. Can J. For. Res. 13, 818-826

Chapin F.S. III, Bloom A.J. Field C.P. \& Waring R.H. (1987) Plant responses to multiple environmental factors. BioScience 37, 49-57

Cote B. \& Dawson J.O. (1986) Autumnal changes in total nitrogen, salt-extractable proteins and amino acids in leaves and adjacent 
bark of black alder, eastern cottonwood and white basswood. Physiol. Plant. 67, 102-108

Denne M.P. \& Atkinson C.J. (1987) Reactivation of vessel expansion in relation to budbreak in sycamore (Acer pseudoplatanus) trees. Can. J. For. Res. 17, 1166-1174

Dickson R.E. (1979) Xylem translocation of amino acids from roots to shoots in cottonwood plants. Can J. For. Res. 9, 374-378

Dickson R.E. (1986) Carbon fixation and distribution in young Populus trees. In: Proc. Crown and Canopy Structure in Relation to Productivity. (Fujimori T. \& Whitehead D., eds.), Forest and Forest Products Res. Inst., Ibaraki, Jpn. pp. 409. 426

Dickson R.E. (1987) Diurnal changes in leaf chemical constituents and ${ }^{14} \mathrm{C}$ partitioning in cottonwood. Tree Physiol. 3, 157-171

Dickson R.E. \& Nelson E.A. (1982) Fixation and distribution of ${ }^{14} \mathrm{C}$ in Populus deltoides during dormancy induction. Physiol. Plant. 54, 393-401

Dickson R.E. \& Shive J.B. Jr. (1982) ${ }^{14} \mathrm{CO}_{2}$ fixation, translocation, and carbon metabolism in rapidly expanding leaves of Populus deltoides. Ann. Bot. 50, 37-47

Dickson R.E., Vogelmann T.C. \& Larson P.R. (1985) Glutamine transfer from xylem to phloem and translocation to developing leaves of Populus deltoides. Plant Physiol. 77, 412-417

Drew A.P. \& Ledig F.T. (1980) Episodic growth and relative shoot:root balance in loblolly pine seedlings. Ann. Bot. 45, 143-148

Eissenstat D.M. \& Caldwell M.M. (1988) Seasonal timing of root growth in favorable microsites. Ecology 69, 870-873

Ericsson T. (1981) Effects of varied nitrogen stress on growth and nutrition in three Salix clones. Physiol. Plant. 51, 423-429

Fisher D.G., Larson P.R. \& Dickson R.E. (1983) Phloem translocation from a leaf to its nodal region and axillary branch in Populus deltoides. Bot. Gaz. 144, 481-490

Franceschi V.R., Wittenbach V.A. \& Giaquinta R.T. (1983) The paraveinal mesophyll of soybean leaves in relation to assimilate transfer and compartmentation. III. Immunohistochemical localization of specific glycopeptides in the vacuole after depodding. Plant Physiol. 72, 586589

Geiger D.R. (1987) Understanding interactions of source and sink regions of plants. Plant Physiol. Biochem. 25, 659-666
Gifford R.M., Thorne J.H., Hitz W.D. \& Giaquinta R.T. (1984) Crop productivity and photoassimilate partitioning. Science 225, 801-808

Glerum C. (1980) Food sinks and food reserves of trees in temperate climates. New Zealand $J$. For. Sci. 10, 176-185

Gordon J.C. \& Larson P.R. (1968) Seasonal course of photosynthesis, respiration, and distribution of ${ }^{4} \mathrm{C}$ in young Pinus resinosa trees as related to wood formation. Plant Physiol. 43, 1617-1624

Gregory R.A. \& Wargo P.M. (1986) Timing of defoliation and its effect on bud development, starch reserves, and sap sugar concentration in sugar maple. Can. J. For. Res. 16, 10-17

Gregory R.A., Williams M.W. Jr., Wong B.L. \& Hawley G.J. (1936) Proposed scenario for dieback and decline of Acer saccharum in northeastern U.S.A. and southeastern Canada. IAWA Bull. n.s., 7, 357-369

Hanson A.D. \& Hitz W.D. (1982) Metabolic responses of mesophytes to plant water deficits. Annu. Rev. Plant Physiol. 33, 163-203

Hanson P.J., Dickson R.E., Isebrands J.G., Crow T.R. \& Dixon R.K. (1986) A morphological index of Quercus seedling ontogeny for use in studies of physiology and growth. Tree Physiol. 2, 273-281

Heichel G.H. \& Turner N.C. (1984) Branch growth and leaf numbers of red maple (Acer rubrum L.) and red oak (Quercus rubra L.): response to defoliation. Oecologia 62, 1-6

Ho L.C. \& Shaw A.F. (1977) Carbon economy and translocation of ${ }^{14} \mathrm{C}$ in leaflets of the seventh leaf of tomato during leaf expansion. Ann. Bot. 41, 833-848

Hoffmann Von G. \& Lyr H. (1973) Charakterisierung des Wachstumsverhaltens von Pflanzen durch Wachstumsschemata. Flora 162, 81-98

Huber S.G. (1986) Fructose-2,6-bisphosphate as a regulatory metabolite in plants. Annu. Rev. Plant Physiol. 37, 233-246

Ingestad T. \& Agren G.I. (1988) Nutrient uptake and allocation at steady-state nutrition. Physiol. Plant. 72, $450-459$

Ingestad T. \& Lund A.B. (1986) Theory and techniques for steady state mineral nutrition and growth of plants. Scand. J. For. Res. 1, 439-453

Ingestad T., Arveby A.S. \& Kahr M. (1986) The influence of ectomycorrhiza on nutrition and growth of Pinus: sylvestris seedling. Physiol. Plant. 68, 575-582 
Isebrands J.G. \& Nelson N.D. (1983) Distribution of $\left({ }^{14} \mathrm{C}\right)$-labeled photosynthates within intensively cultured Populus clones during the establishment year. Physiol. Plant. 59, 9-18

Kang S-M. \& Titus J.S. (1980) Qualitative and quantitative changes in nitrogenous compounds in senescing leaf and bark tissues of the apple. Physiol. Plant. 50, 285-290

Kato T. (1986) Nitrogen metabolism and utilization in Citrus. Hortic. Rev. 8, 181-216

Keeney D.R. (1980) Prediction of soil nitrogen availability in forest ecosystems: a literature review. For. Sci. 26, 159-171

Keltjens W.G., Nieuwenhuis J.W. \& Nelemans J.A. (1986) Nitrogen retranslocation in plants of maize, lupin and cocklebur. Plant Soil 91, 323327

Kramer P.J. \& Kozlowski T.T. (1979) In: Physiology of Woody Plants. Academic Press, New York, pp. 811

Larson P.R. \& Dickson R.E. (1986) ${ }^{14} \mathrm{C}$ translocation pathways in honeylocust and green ash: woody plants with complex leaf forms. Physiol. Plant. 66, 21-30

Lee J.A. \& Stewart G.R. (1978) Ecological aspects of nitrogen assimilation. Adv. Bot. Res. 6, 1-43

MacKown C.T. (1987) Nitrate uptake and assimilation following nitrate deprivation. J. Exp. Bot. 38, 1079-1090

Margolis H.A., Vezina L.P. \& Ouimet R. (1988) Relation of light and nitrogen source to growth, nitrate reductase and glutamine synthetase activity of jack pine seedlings. Physiol. Plant. 72, 790-795

Matyssek R. (1986) Carbon, water and nitrogen relations in evergreen and deciduous conifers. Tree Physiol. 2, 177-187

McLaughlin, S.B., McConathy R.K., Barnes R.L. \& Edwards N.T. (1980) Seasonal changes in energy allocation by white oak (Quercus alba).

Can. J. For. Res. 10, 379-388

Michael D.A., Isebrands J.G., Dickmann D.I. \& Nelson N.D. (1988) Growth and development during the establishment year of two Populus clones with contrasting morphology and phenology. Tree Physiol. 4, 139-152

Millard P. (1988) The accumulation and storage of nitrogen by herbaceous plants. Plant Cell Environ. 11, 1-8

Nadelhoffer K.J., Aber J.D. \& Melillo J.M. (1983) Leaf-litter production and soil organic matter dynamics along a nitrogen-availability gradient in southern Wisconsin (USA). Can. $J$. For. Res. 13, 12-21

Nadelhoffer K.J., Aber J.D. \& Melillo J.M. (1985) Fine roots, net primary production, and soil nitrogen availability: a new hypothesis. Ecology 66, 1377-1390

Nambiar E.K.S. \& Fife D.N. (1987) Growth and nutrient retranslocation in needles of radiata pine in relation to nitrogen supply. Ann. Bot. 60, 147-156

Nelson E.A. \& Dickson R.E. (1981) Accumulation of food reserves in cottonwood stems during dormancy induction. Can. J. For. Res. 11, 145-154

Nelson N.D. \& Isebrands J.G. (1983) Late-season photosynthesis and photosynthate distribution in an intensively-cultured Populus nigra $x$ laurifolia clone. Photosynthetica 17, 537-549

Osmond C.B., Austin M.P., Berry J.A., Billings W.D., Boyer J.S., Dacey J.W.H., Nobel P.S., Smith S.D. \& Winner W.E. (1987) Stress physiology and the distribution of plants. BioScience 37, 38-48

Pate J.S. (1980) Transport and partitioning of nitrogenous solutes. Annu. Rev. Plant Physiol. 31, 313-340

Pate J.S. (1983) Patterns of nitrogen metabolism in higher plants and their ecological significance. In: Nitrogen as an Ecological Factor. (Lee J.A., McNeill S. \& Rorison I.H., eds.), 22nd Symp. Br. Ecol. Soc., Oxford 1981. pp. 225-255

Pearcy R.W., Bjorkman O., Caldwell M.M., Keeley J.E., Monson R.K. \& Strain B.R. (1987) Carbon gain by plants in natural environments. BioScience 37, 21-29

Peoples M.B., Pate J.S., Atkins C.A. \& Bergersen F.J. (1986) Nitrogen nutrition and xylem sap composition of peanut (Arachis hypogaea L. cv. Virginia Bunch). Plant Physiol. 82, 946-951

Philipson J.J. (1988) Root growth in Sitka spruce and Douglas fir transplants: dependence on the shoot and stored carbohydrate. Tree Physiol. 4, 101-108

Rangnekar P.V., Forward D.F. \& Nolan N.J. (1969) Foliar nutrition and wood growth in red pine: distribution of radiocarbon photoassimilated by individual branches of young trees. Can. J. Bot. 47, 1701-1711

Raven J.A. (1985) Regulation of $\mathrm{pH}$ and generation of osmolarity in vascular plants: a costbenefit analysis in relation to efficiency of use of 
energy, nitrogen, and water. New Phytol. 101, 25-77

Rufty T.W., Jr. \& Volk R.J. (1986) Alterations in enrichment of $\mathrm{NO}_{3}^{-}$and reduced-N in xylem exudate during and after extended plant expo-

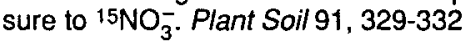

Runge M. (1983) Physiology and ecology of nitrogen nutrition. In: Physiological Plant Ecology III. Responses to the Chemical and Biological Environment. (Lang O.L., Nobel P.S., Osmond C.B. \& Ziegler H., eds.) Springer-Verlag, New York, pp. 163-200

Sagisaka S. \& Araki T. (1983) Amino acid pools in perennial plants at the beginning of growth. Plant Cell Physiol. 24, 479-494

Salsac L., Chaillou S., Morot-Gaudry J.F., Lesaint C. \& Jolinet E. (1987) Nitrate and ammonium nutrition in plants. Plant Physiol. Biochem. 25, 805-812

Sauter J.J. (1981) Seasonal variation of amino acids and amides in the xylem sap of Salix. $Z$. Pflanzenphysiol. 101, 399-411

Sauter J.J. \& Wellenkamp S. (1988) Protein storing vacuoles in ray cells of willow wood (Salix caprea L.). IAWA Bull. 9, 59-65

Schier G.A. (1970) Seasonal pathways of ${ }^{14} \mathrm{C}$ photosynthate in red pine labeled in May, July, and October. For. Sci. 16, 2-13

Schubert K.R. (1986) Products of biological nitrogen fixation in higher plants: synthesis, transport. and metabolism. Annu. Rev. Plant Physiol. 37, 539-574

Schulze E.D. (1982) Plant life-forms and their carbon, water and nutrient relations. Encyclopedia Plant Physiol., n.s., Vol.12B, 616-676

Schulze E.D., Robichaux R.H., Grace J., Rundel P.W. \& Ehleringer J.R. (1987) Plant water balance. BioScience 37, 30-37

Shim K-K. \& Titus J.S. (1985) Accumulation and mobilization of storage proteins in ginkgo shoot bark. J. Korean Soc. Hortic. Sci. 26, 350-360

Sieciechowicz K.A., Joy K.W. \& Ireland R.J. (1988) The metabolism of asparagine in plants. Phytochemistry 27, 663-671

Sleigh P.A., Collin H.A. \& Hardwick K. (1984) Distribution of assimilate during the flush cycle of growth in Theobroma cocao L. Plant Growth Regul. 2, 381-391

Smirnoff N. \& Stewart G.R. (1985) Nitrate assimilation and translocation by higher plants: Comparative physiology and ecological consequences. Physiol. Plant. 64, 133-140
Smith J.L. \& Paul E.A. (1988) Use of an in situ labeling technique for the determination of seasonal ${ }^{14} \mathrm{C}$ distribution in ponderosa pine. Plant Soil 106, 221-229

Stassen P.J.C., Stindt H.W., Strydom D.K. \& Terblanche J.H. (1981) Seasonal changes in nitrogen fractions of young kakamas peach trees. Agroplantae 13, 63-72

Titus J.S. \& Kang S.M. (1982) Nitrogen metabolism, translocation, and recycling in apple trees. Hortic. Rev. 4, 204-246

Tromp J. (1983) Nutrient reserves in roots of fruit trees, in particular carbohydrates and nitrogen. Plant Soil 71, 401-413

Tromp J. \& Ovaa J.C. (1979) Uptake and distribution of nitrogen in young apple trees after application of nitrate or ammonium, with special reference to asparagine and arginine. Physiol. Plant. 45, 23-28

Tromp J. \& Ovaa J.C. (1985) Response of young apple trees to time of nitrogen fertilization with respect to the nitrogen, potassium, and calcium levels in xylem sap, new growth, and the tree as a whole. J. Plant Physiol. 119, 301. 309

Tyrrell L.E. \& Boerner R.J.E. (1987) Larix laricina and Picea mariana: relationships among leaf life span, foliar nutrient patterns, nutrient conservation, and growth efficiency. Can. J. Bot. 65, 1570-1577

van Bel A.J.E., van Leeuwenkamp P. \& van der Schoot C. (1981) Amino acid uptake by various tissues of the tomato plant. Effects of external $\mathrm{pH}$ and light. Z. F'flanzenphysiol. 104, 117-128

van den Driessche R. (1987) Importance of current photosynthate to new root growth in planted conifer seedlings. Can. J. For. Res. 17, 776782

Vitousek P.M. \& IMatson P.A. (1985) Causes of delayed nitrate production in two Indiana forests. For. Sci. 31, 122-131

Vitousek P.M., Gosz J.R., Grier C.G., Melillo J.M. \& Reiners W.A. (1982) A comparative analysis of potential nitrification and nitrate mobility in forest ecosystems. Ecol. Monographs 52, 155-177

Vogelmann T.C., Dickson R.E. \& Larson P.R. (1985) Comparalive distribution and metabolism of xylem-borne amino compounds and sucrose in shoots of Populus deltoides. Plant Physiol. 77, 418-428

Vogelmann T.C., Larson P.R. \& Dickson R.E. (1982) Translocation pathways in the petiole and stem between source and sink leaves of 
Populus deltoides Bartr. ex. Marsh. Planta 156, 345-358

Vogt K.A., Grier C.C., Meier C.E. \& Edmonds R.L. (1982) Mycorrhizal role in net primary production and nutrient cycling in Abies amabilis ecosystems in Western Washington. Ecology 63, 370-380

Wargo P.M. (1979) Starch storage and radial growth in woody roots of sugar maple. Can. J. For. Res. 9, 49-56

Wargo P.M. \& Montgomery M.E. (1983) Colonization by Armillaria mellea and Agrilus bilinea- tus of oaks injected with ethanol. For. Sci. 29 , 848-857

Webb W.L. (1977) Seasonal allocation of photoassimilated carbon in Douglas fir seedlings. Plant Physiol. 60, 320-322

Weissman G.S. (1964) Effect of ammonium and nitrate nutrition on protein level and exudate composition. Plant Physiol. 39, 947-952

Wingsle G., Nasholm T., Lundmark T. \& Ericsson $A$. (1987) Induction of nitrate reductase in needles of Scots pine seedlings by $\mathrm{NO}_{x}$ and $\mathrm{NO}_{3}$. Physiol. Plant. 70, 399-403 